\title{
ECONOMETRIC ANALYSIS OF AGGREGATE DEMAND FOR MEAT IN IMO STATE, NIGERIA
}

\author{
Ohajianya D. O.
}

\begin{abstract}
This study was designed to isolate the determinants of aggregate demand for meat and analyze the demand elasticities of meat in Imo State. Time series data were collected with structured questionnaire along side personal observations from 120 stratified randomly selected households for the period 2000-2003. Data were collected on per capita meat demand, retail price of meat, retail price of dried fish, retail price of iced fish and per capital income, and analyzed using the ordinary least squares (OLS) regression technique. Results show that aggregate demand for meat in Imo State is generally price inelastic. Beef and poultry were found to be normal goods. Dried fish was also found to be close substitute to beef. If the demand for poultry in the State can be projected and appropriate programmes designed to boost local production of poultry, it is expected that in a short while, Imo State would be able to produce adequate quantities of this source of animal protein at affordable prices thereby improving the level of protein intake by the populace.
\end{abstract}

\section{Key words: Aggregate Demand, Meat}

\section{INTRODUCTION}

Nutritional scientist have repeatedly drawn attention to the gross imbalance between animal protein availability and human need for such protein in Nigeria. Oyenuga (1987) was one of the early researchers to evaluate the animal protein supply: demand ration. $\mathrm{He}$ estimated the mean daily requirement of Nigeria's reference person at $61 \mathrm{gm}$. This represents a shortfall of $10 \mathrm{gm}(16.4 \%)$. It is plausible to suggest that, currently this situation may have deteriorated even further in spite of an apparent increase in the nation's animal production. This situation can be remedied through increased intake of protein rich plant food increased consumption of animal products such as beef, lamb, Pork, Mutton, chevon, milk, fish, and poultry. Prices of animal products are beyond the reach of the average Nigerian owing to the increases in the production and maintenance costs of farm animals. Despite those rising cost of animal products, the demand is still believed to increase annually with increase in population and level of income (Fabiyi, 1985), and coupled with the fact that animal protein intake is needed by humans to sustain life.

Although several empirical studies have been conducted on the structure of demand for certain commodities including meat products (Oyenuga, 1987: Fabiyi, 1985, Mba, 1998, Fatunla et al, 1999: Allison-Oguru, 1992), there has not been any such empirical study to determine the structure of aggregate meat demand in Imo State despite the fact that the State has the largest meat markets in South Eastern Nigeria.

This study is therefore designed to identify the factors that determine aggregate demand for meat in the State, and to determine price, income and cross-price elasticities of demand for meat in the State.

\section{METHODOLOGY}

This study was conducted in Imo State. The State presently comprises three agricultural zones, Owerri, Orlu and Okigwe, further sub divided into 27 Local Government Areas (LGAs). The state was stratified into the existing three agricultural zones, and two LGAs, consisting of one rural and one Urban, were purposively selected from each zone. Two communities were randomly selected from each chosen LGA, and 10 households were 
randomly selected from each chosen community giving a sample size of 120 households. The resident extension agents, community leaders and key informants assisted in the preparation of the sampling frame and identification of the selected households.

Primary data were supplemented with information (secondary data) obtained from Federal Office of Statistics, livestock department of the Federal and State Ministries of Agriculture and Natural Resources, text books, Journals, Seminar and Conference papers. Time series data on annual observation on meat demand, retail price of meat, retail price of dried fish, retail price of iced Fish and per capita income in Imo State for the period 20002003. The data were collected through the use of structured questionnaire and personal observations. Data were analyzed using ordinary least Square (OLS) regression technique. It is postulated in this study that aggregate demand for meat in Imo State is determined by factors such as own price, price of dried fish, price of iced fish and per capita income, ceteris paribus.

The above functional relationship can be stated respectively for beef, poultry; and beef and poultry pooled as follows:

$$
\begin{aligned}
& Q_{b}=f\left(X_{1}, X_{2}, X_{3}, X_{4}\right) . \\
& Q_{P}=f\left(X_{1}, X_{2}, X_{3}, X_{4}\right) .
\end{aligned}
$$

$\mathrm{Q}_{\mathrm{b}+\mathrm{P}}=\mathrm{f}\left(\mathrm{X}_{1}, \mathrm{X}_{2}, \mathrm{X}_{3}, \mathrm{X}_{4}\right)$.

Where

$\mathrm{Q}_{\mathrm{b}}=$ per capita demand for beef

$\mathrm{Q}_{\mathrm{p}}=$ per capita demand for poultry

$\mathrm{Q}_{\mathrm{b}+\mathrm{p}}=$ per capita demand for meat generally (beef and poultry pooled)

$\mathrm{X}_{1}=$ Retail price of meat

$\mathrm{X}_{2}=$ Retail price of dried fish

$\mathrm{X}_{3}=$ Retail price of Iced fish

$\mathrm{X}_{4}=$ Per capita income

The power functional form used by Allison- Oguru (1997) was specified in this study for the purpose of empirical estimation of the required demand coefficients as follows:

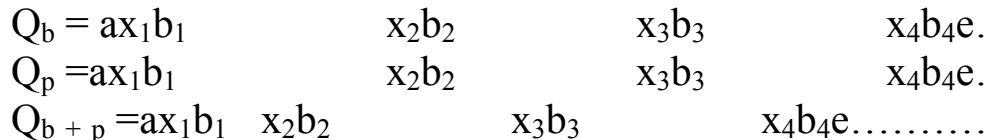

In order to facilitate empirical estimation of the demand coefficients (bi's) in equation (4) through (6), the variables in these equations were transformed into logarithms as follows:

$$
\begin{aligned}
\operatorname{InQ}_{\mathrm{b}} & =\operatorname{Ina}+\mathrm{b}_{1} \operatorname{Inx}_{1}+\mathrm{b}_{2} \operatorname{Inx}_{2}+\mathrm{b}_{3} \operatorname{Inx}_{3}+\mathrm{b}_{4} \operatorname{Inx}_{4}+\mathrm{e} . \\
\operatorname{InQ}_{\mathrm{p}} & =\operatorname{Ina}+\mathrm{b}_{1} \operatorname{Inx}_{1}+\mathrm{b}_{2} \ln \mathrm{x}_{2}+\mathrm{b}_{3} \operatorname{Inx}_{3}+\mathrm{b}_{4} \operatorname{In} \mathrm{x}_{4}+\mathrm{e} \\
\mathrm{InQ}_{\mathrm{b}+\mathrm{P}} & =\operatorname{Ina}+\mathrm{b}_{1} \operatorname{Inx}_{1}+\mathrm{b}_{2} \ln \mathrm{In}_{2}+\mathrm{b}_{3} \operatorname{Inx}_{3}+\mathrm{b}_{4} \operatorname{Inx}_{4}+\mathrm{e} .
\end{aligned}
$$

The coefficients in equation (7) through (9) were estimated using the ordinary least squares (OLS) method of multiple regression analysis. All the assumptions underlying this method of estimation are assumed to hold in this study. It is expected a priori that own price $\left(\mathrm{x}_{1}\right)$ would be negatively related with per capita demand for all types of meat. Conversely, price of iced fish $\left(\mathrm{x}_{3}\right)$ are expected to be positively related with per capita demand for meat, ceteris paribus.

The approach adopted in this study is similar to that of Allison-Oguru (1997), in his study on Econometric Analysis of Aggregate Demand for fish in Rivers State. 


\section{RESULTS AND DISCUSSION}

\section{Estimated Demand Functions}

Table 1 presents the result of the estimated coefficients of the demand functions specified in equation (7) through (9). This result yields the following demand equations.

$$
\operatorname{InQ}_{\mathrm{b}}=\operatorname{In} 1.196+0.095 \operatorname{Inx}_{1}+0.511 \operatorname{Inx}_{2}+0.631 \operatorname{Inx}_{3}+0.381 \operatorname{Inx}_{4 . .}(10)
$$
(3.182)
(2.192)
(3.066)
(1.843)
(1.371)

$\ln \mathrm{Q}_{\mathrm{b}}=\ln 1.387+0.523 \ln \mathrm{x}_{1}-0.879 \ln \mathrm{x}_{2}-0.791 \ln \mathrm{x}_{3}-\quad 0.603 \ln \mathrm{x}_{4} \ldots(11)$

$$
(2.891)(3.513)(-4.891) \quad(-1.349) \quad(-1.882)
$$

$\ln \mathrm{Q}_{\mathrm{b}+\mathrm{p}}=\ln 1.752+0.337 \ln \mathrm{x}_{1}+0.413 \ln \mathrm{x}_{2}-0.328 \ln \mathrm{x}_{3}-0.194 \ln \mathrm{x}_{4} \ldots \ldots(12)$
(2.116) (1.106)
(1.573)
$(-1.569)$
$(-1.573)$

All the demand coefficients in equation (I2) have their expected signs except own price $\left(\mathrm{x}_{1}\right)$ and price of Iced fish $\left(\mathrm{x}_{3}\right)$

\begin{tabular}{|c|c|c|c|}
\hline & & \multicolumn{2}{|c|}{ Types of Meat } \\
\hline $\begin{array}{l}\text { Explanatory Variables and } \\
\text { Important statistics }\end{array}$ & Beef & $\begin{array}{l}\text { Poultry } \\
\left(\mathrm{Q}_{\mathrm{b}}\right)\end{array}$ & $\begin{array}{l}\text { Beef and Poultry } \\
\qquad\left(\mathrm{Q}_{\mathrm{b}+\mathrm{b}}\right)\end{array}$ \\
\hline Constant & $\begin{array}{l}1.196 \\
(3.182)\end{array}$ & $\begin{array}{l}1.387 \\
(2.891)\end{array}$ & $\begin{array}{l}1.752 \\
(2.116)\end{array}$ \\
\hline Retail price of meat $\left(\mathrm{x}_{1}\right)$ & $\begin{array}{l}0.095 \\
(1.192)\end{array}$ & $\begin{array}{l}0.523 \\
(3.513) * *\end{array}$ & $\begin{array}{l}0.337 \\
(1.106)\end{array}$ \\
\hline Retail Price of Dried Fish $\left(\mathrm{x}_{2}\right)$ & $\begin{array}{l}0.511 \\
(3.066)^{* *}\end{array}$ & $\begin{array}{l}-0.879 \\
(-4.891)^{* *}\end{array}$ & $\begin{array}{l}0.413 \\
(2.573)^{*}\end{array}$ \\
\hline Retail price of Iced fish $\left(\mathrm{x}_{3}\right)$ & $\begin{array}{l}0.631 \\
(1.843)\end{array}$ & $\begin{array}{l}-0.791 \\
(-1.349)\end{array}$ & $\begin{array}{l}0.328 \\
(1.569)\end{array}$ \\
\hline Per Capita Income $\left(\mathrm{x}_{4}\right)$ & $\begin{array}{l}0.381 \\
(1.371)\end{array}$ & $\begin{array}{l}-0.603 \\
(-1.882)\end{array}$ & $\begin{array}{l}-0.194 \\
(-1.528)\end{array}$ \\
\hline $\begin{array}{l}\mathrm{R}^{2} \\
\mathrm{~F}\end{array}$ & 0.852 & 0.903 & 0.813 \\
\hline $\mathrm{N}$ & 120 & 120 & 120 \\
\hline
\end{tabular}

Table 1 Regression Coefficients On Aggregate Demand For Meat In Imo State

Figures in parenthesis are t-ratios

* $\quad \mathrm{t}$ - ratios significant at 0.05 level

** $\mathrm{t}$ - ratios significant at 0.01 level.

Source: Summarized from computer output, 2004

The coefficient of own price has a positive sign implying that per capita demand for beef increases with increase in its price. The coefficient of price of iced fish $\left(\mathrm{x}_{3}\right)$ is negative implying that as the retail price of iced fish increases, per capita demand for poultry also decreases. The sign of the per capita income coefficient suggests that beef and poultry are normal goods. This is expected as growth in per capita income tends to increase consumption of non-starchy foods like meat (Idachaba, 1997).

Of the demand coefficients in the equation only that of price of dried fish is statistically significant at the 1 percent level implying that price of dried fish is the most 
important and reliable factor that accounts for variation in per capita demand for meat. The $\mathrm{F}$ value in the equation is statistically significant at the 1 percent level implying that the joint influence of all the explanatory variables on per capita demand for beef is very strong.

In equation (10), only the demand coefficient of the Iced fish $\left(\mathrm{x}_{3}\right)$ has its excepted positive sign. This implies that per capita demand for meat increases with increase in price of Iced fish. The income coefficient in this equation is negative suggesting that iced fish is an inferior good. This is expected given the stigma consumers in the state attach to the consumption of iced fish. All the other explanatory variables in the equation have coefficients that are statistically significant at $1 \%\left(\mathrm{x}_{1}, \mathrm{x}_{3}\right)$ or 5 percent $\left(\mathrm{x}_{2}\right)$ level. Also the Fvalue of this equation indicates that the joint influence of all the explanatory variables on per capita demand for meat is strong.

In equation (11), all the demand coefficients have their excepted sign except that of own price and per capita income. The coefficient of per capita income suggests that per capita demand for beef and poultry pooled (or meat generally) is negatively related with per capita income. Of these demand coefficients only that of price of iced fish is statistically significant at 5 percent level. The F-value is also statistically significant at 1 percent level.

These results suggest that aggregate demand of meat in Imo State is jointly determined by factors such as own price, price of related commodities like dried fish and iced fish, and per capita income.

For purposes of predicting future demand for meat in the state; own price, price of dried fish and price of iced fish are the most important and reliable explanatory variables that determine per capita demand for beef or poultry.

In the case of beef, it is only price of dried fish that is a relevant variable while per capita demand for beef and poultry pooled is determined by price of dried fish. All the estimated demand equations show positive relationship between own price and per capita demand of types of meat. This result conforms to a priori expectation, and is similar to the findings of previous studies conducted by Allison-Oguru (1992), Fatunla et al (1997) and Fabiyi (1985). The positive sign exhibited by the demand coefficient of own price could be attributed to shortfall in meat supply or excessive meat demand.

\section{Demand Elasticities}

The estimated own price elasticity coefficients for beef, poultry, beef and poultry pooled are $0.095,0.523$ and 0.337 for price levels ranging between $\mathrm{N} 500 / \mathrm{kg}$ and N700/kg (Table 2). These price elasticity coefficients indicate that a 1 percent increase in price of any of the types of meat studied induces a less than proportionate increase in per capita demand for that type of meat. This implies that demand for all types of meat in Imo State is price inelastic.

\section{Table 2: Estimated Demand Elasticities For Meat in Imo State}

\begin{tabular}{lllll}
\multirow{2}{*}{ Commodity } & Price & \multicolumn{3}{l}{ IncomeCross-Price Elasticity } \\
& Elasticity & Elasticity & Dried fish & Iced Fish \\
\hline Beef $\left(\operatorname{In} \mathrm{Q}_{\mathrm{b}}\right)$ & 0.095 & 0.381 & 0.511 & \multirow{2}{*}{0.631} \\
Poultry $\left(\right.$ In $\left.\mathrm{Q}_{\mathrm{p}}\right)$ & 0.523 & 0.603 & -0.8790 .791 & \\
Beef and Poultry $\left(\operatorname{In} \mathrm{Q}_{\mathrm{b}+\mathrm{p}}\right)$ & 0.337 & 0.194 & $0.413 \quad 0.328$ & \\
\hline
\end{tabular}

Source: Summarized from Demand Equations.

Income elasticity of demand coefficients of beef, Poultry, beef and Poultry pooled are 0.381 , 0.603 and 0.194 respectively for levels of per capita income ranging between N68,000- 
N265,000 per annum. These results imply that beef, poultry, and beef and poultry pooled are normal goods. Cross price elasticity coefficients of dried fish and iced fish with each type of meat indicates that dried fish is a substitute for beef and a complement for poultry, which suggest that both commodities are substitutes of meat generally. This result also indicates that an increase in the relative prices of dried fish and iced fish would induce increased per capita demand for meat in the State, ceteris paribus .

\section{CONCLUSION}

The result of this study shows that aggregate demand for meat is generally price inelastic in Imo State. Beef and poultry are found to be normal goods with positive income elasticity coefficients. Therefore, as level of per capital income increases in the state, per capital demand for beef and poultry is expected to increase. This also suggests that meat consumers in the state have similar preference for beef and poultry. It is therefore suggested that government encourages poultry production through subsidies on poultry production and maintenance inputs.

Dried fish was found to be a close substitute to beef in the state. Consumers can therefore shift their preference from one to the other depending on their relative prices. Beef and poultry production should be given equal share in the state's agricultural improvement programmes and the farmers need to be encouraged to produce enough to satisfy consumers demand. If the demand of meat particularly poultry, in the state can be projected and appropriate programmes designed to boost local production of poultry, it is expected that in a short while, Imo State would be able to produce adequate quantities of this source of animal protein at affordable prices thereby improving the level of protein intake by the populace.

\section{REFERENCES}

Allison- Oguru, E.A (1992). The Economics of fish production in selected areas of Rivers State. Paper presented to the Department of Agricultural Economics, Rivers State University of Science and Technology, Port-Harcourt, PP.1-3

Allison - Oguru, E. A (1997). Econometric analysis of Aggregate Demand for fish in Rivers state, Nigeria (1990-1997). Delta Agriculturist, 1 (1), 1-5.

Fabiyi, Y.L (1985). Demand for fish in Calabar, Cross Rivers State, Nigeria. In Proceedings of the $4^{\text {th }}$ Annual Conference of the fisheries society of Nigeria, Port Harcourt, pp 62-70.

Fatunla G.T, Oludimu O.L and Ladipo, O.O (1999).A Quantitative Analysis of Demand for fish in Nigeria. In proceedings of the $2^{\text {nd }}$ Annual Conference of the fishers society of Nigeria, Calabar, pp.201-206.

Idachaba, S.F (1997). "Elements of Rural Economics" Ibadan University Press, Ibadan pp. 23-24.

Mba . A.U (1998). Meat Production in Nigeria. Problems and prospects. In Nutrition and food Policy in Nigeria. Pp.90-91.

Oyenuga, A.U (1987). Fundamental Strategies for Livestock Production in Nigeria. Nigerian Journal of Animal Production, Vol.14, no.1, pp.20-25. 